\title{
POLA PENGGUNAAN ALAT TANGKAP IKAN DI DESA KETAPANG BARAT, KABUPATEN SAMPANG, JAWA TIMUR
}

\author{
Maulana Firdaus \\ Balai Besar Penelitian Sosial Ekonomi Kelautan dan Perikanan \\ JI. KS. Tubun Petamburan VI Jakarta 10260 \\ Telp. (021) 53650162, Fax. (021)53650159 \\ e-mail: mr_firda@hotmail.com \\ Diterima 20 Februari 2013- Disetujui 23 Mei 2013
}

\begin{abstract}
ABSTRAK
Teknik penangkapan ikan telah berkembang dari cara tradisional menjadi cara non konvensional. Hal ini ditunjang oleh perkembangan teknologi penangkapan ikan dari alat yang paling sederhana hingga yang lebih modern. Pada dasarnya dalam suatu operasi penangkapan ikan penggunaan bermacam-macam jenis alat tangkap ikan itu dibolehkan. Alat tangkap disesuaikan dengan spesifikasi jenis target ikan yang akan ditangkap. Nelayan di Desa Ketapang Barat, Kabupaten Sampang memiliki beragam jenis alat tangkap yang digunakan, namun alat tangkap tangkap tersebut tidak dapat digunakan terus menerus, hal ini berkaitan dengan perubahan musim ikan yang terjadi pada wilayah perairan tersebut. Terjadinya perubahan musim ikan tentu saja merubah alat tangkap yang akan digunakan oleh nelayan. Tulisan ini bertujuan untuk mengetahui pola penggunaan alat penangkapan ikan oleh nelayan di Kabupaten Sampang dengan kasus di Desa Ketapang Barat. Hasil kajian menunjukkan bahwa ada 5 jenis alat tangkap yang mayoritas digunakan oleh nelayan di Desa Ketapang Barat, yaitu ; (1) gill net, (2) payang dan (3) jaring millennium, (4) jaring kejer dan (5) trammel net. Alat tangkap gill net digunakan pada bulan Maret, April dan Mei; alat tangkap payang digunakan pada bulan Februari, Agustus, Oktober dan November; alat tangkap trammel net digunakan pada bulan Februari, Maret, November dan Desember; alat tangkap kejer digunakan pada bulan Mei dan Juni ; serta alat tangkap jaring millenium digunakan pada bulan Januari, Februari, Oktober, November dan Desember.
\end{abstract}

Kata kunci: pola penggunaan, alat tangkap

Abstract : Patterns of Fishing Gears in Ketapang Barat Village, Sampang Regency, East Java. By Maulana Firdaus.

Fishing techniques has evolved from traditional became to non convensional way. This is supported by the development of the most simple technology to the more modern. Basically in a fishing operation the use of various types of fishing gears that allowed. Gears tailored to the specifications of the target species of fish to be caught. Fishermen in the Ketapang Barat village, Sampang Regency has a variety of gear types used, but the fishing gear can not be used continuously, it is related to the seasonal changes that occur in fish these waters. Fishing seasons change course change gear to be used by fishermen. This paper aims to determine the pattern of use of fishing gear by fishermen in Sampang regency with the case in the village of Ketapang West. Fishing seasons change course change gear to be used by fishermen. This paper aims to determine the pattern of use of fishing gears by fishermen in Sampang Regency with the case in the Ketapang Barat Villaget. The findings showed that there are 5 types of fishing gears used by the majority of the fishermen in the Ketapang Barat Villaget, namely: (1) gill net, (2) payang and (3) net millennium, (4) net kejer and (5) trammel net. Gill net used in March, April and May; payang used in February, August, October and November; trammel net used in February, March, November and December; kejer nets used in May and June and millenium nets used in January, February, October, November and December.

Keywords : Patterns of use, fishing gear

\section{PENDAHULUAN}

Sejak zaman dahulu teknik penangkapan ikan telah berkembang dari tradisional hingga cara non konvensional. Hal ini ditunjang oleh perkembangan teknologi penangkapan ikan dari alat yang paling sederhana, yaitu tombak dan pancing, hingga jaring yang berukuran sangat besar (Brandt, 1984). Menurut Kusnadi (2002), pengoperasian alat tangkap ikan yang berskala besar dan lebih modern seperti trawl, purse seine, long line dan pole and line sudah sejak lama dilakukan oleh nelayan asing dari negara tetangga terutama Jepang dan Taiwan dan mulai dikembangkan oleh masyarakat Indonesia terutama di Sumatera dan Jawa yaitu sekitar pertengahan tahun 1970-an.

Pengelolaan dan pemanfaatan sumberdaya ikan terkait langsung dengan aktivitas penangkapan ikan yang dilakukan oleh masyarakat. Pada dasarnya dalam suatu operasi penangkapan ikan dengan menggunakan bermacam-macam jenis alat tangkap ikan itu dibolehkan. Alat tangkap yang digunakan disesuaikan dengan spesifikasi jenis target ikan yang akan ditangkap. Misalkan untuk menangkap jenis ikan pelagis dapat 
menggunakan jaring insang (Gill Net) dan pukat cincin ikan (Anonim, 2010). Alat tangkap yang digunakan oleh nelayan pada kenyataannya memiliki keragaman antar satu dan lainnya, baik dari segi jenis alat tangkap yang digunakan maupun jumlah alat tangkap yang digunakan. Ada nelayan yang menggunakan hanya satu jenis alat tangkap dalam satu armada, namun jumlahnya banyak dan ada juga nelayan yang menggunakan berbagai jenis alat tangkap (lebih dari satu) dalam satu armada.

Hal ini sejalan dengan hasil penelitian yang dilakukan oleh Hurasan et al. (1993) yang menunjukkan bahwa dalam usaha perikanan pelagis kecil di Kabupaten Maluku Tengah, Kotamadya Ambon dan Maluku Utara, nelayan menggunakan alat tangkap yang sangat beragam (multy gears) yang antara lain jaring insang (Gill Net), pancing bagan (lift net) dan jaring lingkar (mini purse seine). Kondisi ini terjadi pula pada nelayan yang ada di Kabupaten Sampang, Jawa Timur yang memiliki beragam jenis alat tangkap yang digunakan. Kabupaten Sampang dikenal sebagai salah satu wilayah penghasil ikan di Pulau Jawa, dimana pada tahun 2007 produksi perikanan tangkapnya mencapai 12 ribu ton (Bappenas, 2009). Ada berbagai jenis ikan yang dihasilkan di wilayah ini, seperti jenis ikan demersal, seperti udang, kepiting dan lobster serta jenis ikan pelagis kecil, seperti ikan teri, tongkol, kembung dan cakalang. Berdasarkan hal tersebut, ada berbagai macam jenis alat tangkap yang digunakan oleh nelayan di Kabupaten Sampang untuk menangkap ikan jenis tersebut. Berdasarkan laporan tahunan dinas kelautan dan perikanan Kabupaten Sampang pada tahun 2010, diketahui ada beberapa macam jenis alat tangkap yang digunakan oleh nelayan, antara lain adalah payang, Gill Net, trammel net, purse seine, dogol dan pancing.

Nelayan di Kabupaten Sampang menggunakan setiap jenis alat tangkap sesuai dengan target ikan yang akan ditangkap. Untuk menangkap ikan teri dan ikan pelagis kecil lainnya biasanya menggunakan payang, sedangkan untuk menangkap udang atau kepiting dapat menggunakan trammel net. Namun, pada kenyataannya setiap alat tangkap tidak dapat digunakan terus menerus, hal ini berkaitan dengan perubahan musim ikan yang terjadi pada wilayah perairan tersebut. Terjadinya perubahan musim ikan tentu saja merubah alat tangkap yang akan digunakan oleh nelayan. Berdasarkan uraian tersebut, maka tulisan ini bertujuan untuk mengetahui pola penggunaan alat penangkapan ikan oleh nelayan di Kabupaten Sampang dengan kasus di Desa Ketapang Barat, Kecamatan Ketapang, Kabupaten Sampang, Jawa Timur.

\section{METODOLOGI}

\section{Lokasi dan Waktu Penelitian}

Penelitian ini dilakukan di Desa Ketapang Barat, Kecamatan Ketapang, Kabupaten Sampang, Jawa Timur. Kabupaten Sampang merupakan salah satu wilayah di pesisir pantai utara jawa yang memiliki potensi ikan pelagis kecil, khususnya ikan teri terbesar di Jawa Timur. Lokasi ini merupakan salah satu lokasi penelitian Panelkanas (Panel Kelautan dan Perikanan Nasional) yang dilakukan oleh Balai Besar Penelitian Sosial Ekonomi Kelautan dan Perikanan. Kegiatan penelitian dilaksanakan pada bulan Mei 2011.

\section{Jenis dan Sumber Data}

Data yang dipergunakan terutama dari data primer yang dikumpulkan dari hasil wawancara mendalam dengan informan kunci secara individual dengan menggunakan daftar pertanyaan terstruktur. Informan ditentukan dengan menggunakan teknik purposive sampling dengan pertimbangan untuk memenuhi kebutuhan data yang diinginkan yaitu sebanyak 40 orang nelayan di Desa Ketapang Barat. Informan yang dipilih yaitu nelayan dengan status sebagai pemilik kapal yang merangkap menjadi nahkoda. Data sekunder diperoleh melalui studi pustaka, serta informasi dari instansi-instansi terkait baik pemerintah dan swasta.

\section{Metode Pengumpulan dan Analisis Data}

Penelitian ini menggunakan pendekatan studi kasus, menggunakan data yang terkait dengan variabel-variabel terpilih untuk menggambarkan pola penggunaan alat tangkap ikan oleh nelayan pada lokasi penelitian. Data-data tersebut dikumpulkan melalui wawancara dengan informan secara individual dengan menggunakan daftar pertanyaan terstruktur. Informan ditentukan dengan menggunakan teknik purposive sampling. Mengacu pada Singarimbun (1989), Jumlah informan dalam penelitian ini yaitu sebanyak 40 orang, didasarkan pada syarat kecukupan informasi menurut justifikasi peneliti. Data primer dan sekunder yang dikumpulkan kemudian dianalisis secara deskriptif dengan tujuan untuk menyederhanakan dara kedalam bentuk yang mudah untuk dipahami.

\section{KARAKTERISTIK NELAYAN DI DESA KETAPANG BARAT}

Pada penelitian ini nelayan yang dijadikan responden yaitu sebanyak 40 orang yang bertempat tinggal di Desa Ketapang Barat. Mayoritas penduduk asli setempat dan berasal dari etnis yang sama yaitu Madura. Jika ditinjau dari segi usia, pengalaman usaha dan tingkat pendidikan sangat beragam. Untuk kategori usia, yaitu berkisar $<25$ tahun sampai dengan $>60$ tahun. Untuk responden yang usianya $<25$ tahun yaitu berusia 15 tahun sebanyak 1 orang. Responden ini merupakan anak dari nelayan yang melanjutkan kegiatan usaha orang tuanya.

Pada penelitian ini mayoritas usia responden yaitu berkisar antara 46 - 60 tahun yaitu sebanyak $50 \%$. Jika dikaitkan dengan pengalaman usaha, pada umumnya nelayan yang berusia lebih dari 25 tahun 
memiliki pengalaman usaha lebih dari 5 tahun, bahkan untuk nelayan yang berusia diatas 45 tahun, rata-rata pengalaman usahanya adalah dapat mencapai 10 tahun. Sehingga dapat dikatakan bahwa semakin tinggi tingkat usia nelayan maka memiliki pengalaman yang lebih lama pula. Dari hal tersebut dapat diketahui profesi nelayan telah menjadi mata pencaharian utama oleh masyarakat di Desa Ketapang Barat sejak lama. Secara rinci, karakteristik nelayan berdasarkan usia, pengalaman usaha, tingkat pendidikan dan jumlah anggota keluarga dapat dilihat pada Tabel 1.

Pada umumnya nelayan di Desa Ketapang Barat memiliki tingkat pendidikan yang rendah, ada sebanyak $33 \%$ responden tidak mengenyam pendidikan (tidak sekolah), sebanyak $23 \%$ responden tidak tamat SD dan sebanyak $45 \%$ responden tamat SD. Tingkat pendidikan tertinggi adalah tamat SD. Berdasarkan hasil penelitian diperoleh informasi bahwa nelayan beranggapan untuk menjadi seorang nelayan yang handal tidak diperlukan tingkat pendidikan yang tinggi, namun hanyalah keberanian dan kebiasaan saja. Walaupun demikian tingkat pendidikan sangatlah berpengaruh terhadap keberlanjutan usaha penangkapan ikan. Contohnya, bila berasumsi bahwa yang tidak sekolah tidak dapat membaca dan menulis, maka hal tersebut akan berpengaruh terhadap upaya peningkatan wawasan dan pengetahuan masyarakat terutama tentang teknologi penangkapan, penanganan hasil tangkapan, pengolahan hasil tangkapan, dan introduksi penggunaan alat tangkap yang ramah lingkungan, yang mungkin didapatkan melalui media cetak, leaflet, buku, brosur atau booklet yang dibagikan kepada nelayan.

Berdasarkan hasil wawancara, salah satu penyebabnya mereka tidak sekolah yaitu karena minimnya sarana pendidikan dan sebagian responden lebih tertarik untuk ikut melaut bersama orang tua mereka sehingga mendapatkan penghasilan (uang). Faktor utama yang diungkapkan oleh sebagian besar responden yang tidak tamat sekolah dasar yaitu bukan karena biaya, namun disebabkan keinginan anak-anak nelayan pada saat itu untuk memperoleh penghasilan (uang). Fenomena itupun masih ada sampai saat dilakukannya penelitian ini, namun seiring banyaknya sarana dan metode pendidikan yang ada saat ini jumlahnya sudah semakin berkurang, sebagian besar anak-anak nelayan sudah ada yang mencapai tingkat pendidikan SLTA dan SLTP. Berdasarkan jumlah anggota rumah tangga, mayoritas responden tergolong dalam keluarga inti yaitu berjumlah antara 3-4 orang, yang terdiri dari orang tua (ayah dan ibu) serta anak, yaitu

Tabel 1. Karakteristik Responden Berdasarkan Usia, Pengalaman Usaha, Tingkat Pendidikan dan Jumlah Anggota Keluarga Tahun 2012.

\begin{tabular}{|c|c|c|c|}
\hline \multirow{2}{*}{ No } & \multirow{2}{*}{ Uraian } & \multicolumn{2}{|c|}{ Jumlah Responden } \\
\hline & & Orang & $\%$ \\
\hline \multirow[t]{6}{*}{1} & Usia & & \\
\hline & $<25$ Tahun & 1 & 3 \\
\hline & 25 - 45 Tahun & 18 & 45 \\
\hline & 46-60 Tahun & 20 & 50 \\
\hline & > 60 Tahun & 1 & 3 \\
\hline & Jumlah & 40 & 100 \\
\hline \multirow[t]{6}{*}{2} & Pengalaman usaha & & - \\
\hline & a. $<5$ Tahun & 1 & 3 \\
\hline & b. 5- 10 Tahun & 5 & 13 \\
\hline & c. 11- 20 Tahun & 15 & 38 \\
\hline & $d>20$ Tahun & 19 & 48 \\
\hline & Jumlah & 40 & 100 \\
\hline \multirow[t]{7}{*}{3} & Tingkat pendidikan & & - \\
\hline & Tidak Sekolah & 13 & 33 \\
\hline & Tidak Tamat SD & 9 & 23 \\
\hline & SD & 18 & 45 \\
\hline & SLTP & - & - \\
\hline & SLTA & - & - \\
\hline & Jumlah & 40 & 100 \\
\hline \multirow[t]{5}{*}{4} & Jumlah anggota rumah tangga & & - \\
\hline & 2 orang & 6 & 15 \\
\hline & 3-4 orang & 25 & 63 \\
\hline & $>4$ orang & 9 & 23 \\
\hline & Jumlah & 40 & 100 \\
\hline
\end{tabular}

Sumber : Data Primer Diolah, 2011. 
sebanyak 63\%. Sedangkan untuk responden yang memiliki jumlah anggota rumah tangga $>4$, selain keluarga inti yang tinggal dalam satu atap namun ada juga anggota dari luar keluarga inti yang ikut tinggal bersama dalam satu atap seperti, keponakan, paman, orang tua dan menantu.

Jika dilihat dari jenis armada atau perahu yang digunakan, seluruh responden menggunakan perahu berukuran kurang dari $10 \mathrm{GT}$. Ada tiga jenis alat tangkap yang digunakan oleh nelayan untuk menangkap ikan jenis pelagis kecil yaitu payang, Gill Net dan jaring millenium, sedangkan alat tangkap lainnya yang digunakan oleh nelayan untuk menangkap jenis ikan demersal antara lain trammel net, dan jaring kejer (jaring rajungan). Pada dasarnya usaha penangkapan ikan oleh nelayan di Desa Ketapang Barat dapat dibagi berdasarkan pada kepemilikan aset utama, seperti perahu dan alat tangkap, serta status usahanya, seperti pemilik atau ABK. Namun, pada tulisan ini nelayan dikelompokkan berdasarkan kepemilikan aset utama alat tangkap yang digunakan. Hal ini dilakukan karena, semua nelayan yang dijadikan responden memiliki status usaha yang sama, yaitu sebagai pemilik dan menggunakan ukuran kapal yang seragam, yaitu $<10 \mathrm{GT}$.

Berdasarkan jenis alat tangkap yang digunakannya, nelayan di Desa Ketapang Barat dapat dikelompokkan menjadi 9 (Tabel 2). Nelayan di Desa Ketapang Barat dapat dikategorikan sebagai nelayan multy gears atau menggunakan lebih dari satu alat tangkap dalam usahanya. Mayoritas nelayan menggunakan alat tangkap Gill Net dan paying, sedangkan yang menggunakan alat tangkap jaring millennium sangat jarang. Hal ini dikarenakan harga jaring millennium tergolong mahal bagi nelayan, karena daya beli nelayan sangat rendah. Setiap jenis alat tangkap yang digunakan oleh nelayan di Desa Ketapang Barat memiliki spesifikasi yang khas terhadap ikan yang menjadi target sasaran utamanya.
Untuk jenis alat tangkap Gill Net digunakan oleh nelayan dengan hasil tangkapan ikan utamanya adalah ikan kembung, alat tangkap payang dengan hasil tangkapan ikan utamanya adalah ikan teri, untuk alat tangkap jaring millennium dengan hasil tangkapan ikan utamanya adalah ikan cakalang, tongkol dan tenggiri, sedangkan untuk alat tangkap trammel net dan jaring kejer adalah udang dan rajungan.

\section{MUSIM PENANGKAPAN DAN POLA PENGGUNAAN ALAT TANGKAP}

Berdasarkan beberapa hasil penelitian mengenai karakteristik usaha penangkapan ikan pelagis kecil, besarnya tingkat produksi jenis ikan ini selain dipengaruhi oleh ketersediaan stok sumber daya ikan, juga dipengaruhi oleh siklus musiman (Taeran, 2007; Abdullah, 2011). Siklus musiman sangat menentukan terhadap keberlangsungan usaha penangkapan ikan yang diusahakan oleh nelayan. Musim penangkapan di Indonesia dikenal adanya empat musim yang sangat mempengaruhi kegiatan penangkapan, yaitu musim barat, musim timur, musim peralihan awal tahun dan musim peralihan akhir tahun. Kedua musim peralihan tersebut sering disebut sebagai musim pancaroba. Keempat musim tersebut secara teratur berputar silih berganti sepanjang tahun akibat adanya angin muson atau angin yang bergerak dan bertiup secara periodic diatas wilayah Indonesia (Gunawan, 2004).

Secara garis besar musim penangkapan yang dilakukan oleh nelayan di Desa Ketapang Barat dapat dibagi kedalam 3 musim, yaitu musim puncak, musim peralihan dan musim paceklik. Tidak ada acuan secara pasti terhadap waktu saat terjadinya pengelompokkan musim penangkapan tersebut. Pada penelitian ini yang menjadi acuan pengelompokkan terjadinya musim penangkapan berdasarkan hasil wawancara dengan responden yang didukung oleh data produksi setiap

Tabel 2. Jumlah Nelayan Berdasarkan Jenis Alat Tangkap yang Digunakannya di Desa Ketapang Barat, Kabupaten Sampang, 2011.

\begin{tabular}{|c|c|c|c|}
\hline No & Jenis Alat Tangkap yang Digunakan & Jumlah (Orang) & Persentase (\%) \\
\hline 1 & Gill Net, Jaring Kejer, Trammel Net & 2 & 5 \\
\hline 2 & Gill Net, Payang & 1 & 3 \\
\hline 3 & Gill Net, Payang, Trammel Net & 22 & 55 \\
\hline 4 & Gill Net, Payang, Trammel Net, Jaring Kejer & 7 & 18 \\
\hline 5 & Gill Net, Payang, Trammel Net, Jaring Millennium & 1 & 3 \\
\hline 6 & Jaring Millenium & 2 & 5 \\
\hline 7 & Payang, Jaring Kejer, Trammel Net & 2 & 5 \\
\hline 8 & Payang, Jaring Millennium, Trammel Net & 1 & 3 \\
\hline 9 & Payang, Trammel Net & 2 & 5 \\
\hline & JUMLAH & 40 & 100 \\
\hline \multicolumn{4}{|c|}{ Keterangan: } \\
\hline $\begin{array}{ll}\text { 1. } & \text { Gil } \\
\text { 2. } & J a r \\
\text { 3. } & \text { TrC } \\
\text { 4. } & J a r\end{array}$ & $\begin{array}{l}\text { et istilah lokal di lokasi penelitian adalah jaring nylon } \\
\text { Kejer istilah lokal di lokasi penelitian adalah jaring begadang } \\
\text { nel Net istilah lokal di lokasi penelitian adalah jaring gondrong } \\
\text { Millennium istilah lokal di lokasi penelitian adalah jaring aserehe }\end{array}$ & & \\
\hline
\end{tabular}


responden. Rata-rata lamanya waktu penangkapan dengan menggunakan alat tangkap payang yaitu kurang lebih $10 \mathrm{Jam} /$ Trip. Hal ini menunjukkan bahwa alat tangkap payang beroperasi tidak jauh dari tempat pendaratan ikan (fishing base). Pada Tabel 3 dapat dilihat waktu musim penangkapan ikan di Desa Ketapang Barat yang terjadi pada tahun 2010.

Musim puncak penangkapan ikan yang terjadi berdasarkan jenis ikan yang tertangkap. Pada tahun 2010, nelayan di Desa Ketapang Barat mengalami musim puncak sebanyak tujuh kali. Lamanya musim puncak pada setiap bulannya hanya berlangsung sekitar $2-3$ hari saja. Pada bulan Februari terjadi musim puncak udang nelayan di lokasi penelitian juga ada yang menggunakan alat tangkap lainnya yaitu jaring kejer dan trammel net, kedua jenis alat tangkap ini digunakan untuk menangkap jenis ikan golongan crustacea seperti udang dan rajungan. Masing-masing alat tangkap yang dimiliki oleh nelayan digunakan pada waktu-waktu tertentu sesuai dengan karakter alat tangkap tersebut terkait spesifikasi jenis ikan sasaran penangkapannya. Penggunaan alat tangkap dapat diketahui berdasarkan kelimpahan jenis ikan tertentu pada perairan di lokasi penelitian. Berdasarkan hasil penelitian, untuk alat tangkap jenis (1) Gill Net jenis ikan yang tertangkap antara lain adalah ikan kembung, ikan layur, tongkol dan lainnya, (2) payang

Tabel 3. Musim Penangkapan Ikan Jenis Pelagis Kecil di Desa Ketapang Barat, Kabupaten Sampang, Tahun 2010.

\begin{tabular}{|c|c|c|c|c|c|c|c|c|c|c|c|c|c|}
\hline \multirow{2}{*}{ No } & \multirow{2}{*}{ Musim Penangkapan } & \multicolumn{12}{|c|}{ Waktu Penangkapan (Bulan) } \\
\hline & & 1 & 2 & 3 & 4 & 5 & 6 & 7 & 8 & 9 & 10 & 11 & 12 \\
\hline 1 & Musim puncak & & & & & & & & & & & & \\
\hline 2 & Musim peralihan & & & & & & & & & & & & \\
\hline 3 & Musim paceklik & & & & & & & & & & & & \\
\hline
\end{tabular}

dan lobster, pada bulan April - Mei terjadi musim puncak ikan kembung dan rajungan, pada bulan Agustus dan Oktober terjadi musim puncak ikan teri dan pada bulan Desember terjadi musim puncak ikan tongkol dan udang, Seperti diungkapkan sebelumnya, acuan yang digunakan dalam menentukan musim penangkapan di Desa Ketapang Barat adalah berdasarkan hasil wawancara serta data produksi nelayan. Sebagai contoh untuk musim puncak ikan teri yang terjadi pada bulan Agustus dan Oktober dimana hasil tangkapan dapat mencapai $100 \mathrm{Kg} /$ Trip sedangkan pada saat musim paceklik ikan teri tidak dapat ditemui. Pada musim peralihan, hasil tangkapan ikan teri hanya sekitar 2-7 Kg/Trip.

Terkait dengan penggunaan alat tangkap, ada 3 jenis alat tangkap yang digunakan oleh nelayan di lokasi penelitian untuk menangkap jenis ikan pelagis kecil, antara lain adalah (1) Gill Net, (2) Payang dan (3) Jaring Millennium. Selain ke-3 jenis alat tangkap tersebut, jenis ikan yang tertangkap antara lain adalah ikan teri, ikan kembung dan tongkol, (3) jaring millenium jenis ikan yang tertangkap antara lain adalah ikan tongkol, kembung, cakalang dan tenggiri (4) jaring kejer jenis ikan yang tertangkap adalah rajungan, kepiting dan lainnya, dan (5) alat tangkap trammel net jenis ikan yang tertangkap adalah udang. Pada Tabel 4 dapat dilihat secara rinci kalender penangkapan berdasarkan waktu penggunaan alat tangkap.

Jika dilihat dari penggunaan alat tangkap untuk jenis ikan pelagis diketahui bahwa musim ikan pelagis (ikan teri, kembung, tongkol, tenggiri dan cakalang) di lokasi penelitian yaitu pada bulan Februari, April, Mei, Agustus dan Oktober. Ke-5 bulan ini dapat dikatakan sebagai musim puncak bagi jenis ikan pelagis kecil pada perairan di lokasi penelitian. Berdasarkan Tabel 4, diketahui bahwa jenis alat tangkap yang sering digunakan secara berurutan adalah alat tangkap payang,

Tabel 4. Kalender Penangkapan Ikan Berdasarkan Waktu Penggunaan Alat Tangkap di Desa Ketapang Barat, Kabupaten Sampang, 2011.

\begin{tabular}{|c|c|c|c|c|c|c|c|c|c|c|c|c|c|c|}
\hline \multirow{2}{*}{ No } & \multirow{2}{*}{ Jenis Alat Tangkap } & \multicolumn{12}{|c|}{ Waktu Penggunaan Alat Tangkap (Bulan) } & \multirow{2}{*}{$\begin{array}{c}\text { Jumlah Rata-rata } \\
\text { Trip/BIn }\end{array}$} \\
\hline & & 1 & 2 & 3 & 4 & 5 & 6 & 7 & 8 & 9 & 10 & 11 & 12 & \\
\hline 1 & Gill Net & & & & & & & & & & & & & 24 \\
\hline 2 & Payang & & & & & & & & & & & & & 22 \\
\hline 3 & Trammel Net & & & & & & & & & & & & & 14 \\
\hline 4 & Kejer & & & & & & & & & & & & & 10 \\
\hline 5 & Millenium & & & & & & & & & & & & & 17 \\
\hline
\end{tabular}

Sumber : Data Primer Diolah, 2011. 
jaring millennium dan Gill Net. Penggunaan ketiga jenis alat tangkap ini menunjukkan bahwa nelayan di Desa Ketapang lebih dominan menangkap ikan jenis pelagis kecil. Namun jika terjadi musim penangkapan ikan yang sama, contohnya pada bulan Februari terjadi musim ikan pelagis kecil seperti ikan kembung dan juga udang, maka adanya kecenderungan nelayan di Desa Ketapang Barat lebih memilih menggunakan alat tangkap trammel net untuk menangkap udang. Hal ini disebabkan harga jual udang yang lebih tinggi dibandingkan ikan kembung. Nelayan yang memiliki alat tangkap payang lebih memilih menggunakan alat tangkap trammel net.

Berdasarkan Tabel 4, diketahui bahwa pada tahun 2010 penggunaan alat tangkap Gill Net lebih dominan digunakan pada bulan Maret, April dan Mei, untuk alat tangkap payang dominan digunakan pada bulan Februari, Agustus, Oktober dan November, untuk alat tangkap trammel net dominan digunakan pada bulan Februari, Maret, November dan Desember, untuk alat tangkap kejer dominan digunakan pada bulan Mei dan Juni, serta untuk alat tangkap jaring millenium dominan digunakan pada bulan Januari, Februari, Oktober, November dan Desember. Pada penelitian ini yang menjadi acuan waktu saat terjadinya musim penangkapan berdasarkan hasil wawancara dengan responden yang didukung oleh data produksi dan trip penangkapan. Namun mengingat adanya perubahan cuaca yang tidak dapat diprediksikan pada akhir-akhir ini, besar kemungkinannya jika pada tahuntahun selanjutnya akan terjadi perubahan musim penangkapan.

\section{KESIMPULAN}

Terkait dengan penggunaan alat tangkap, ada 5 jenis alat tangkap yang mayoritas digunakan oleh nelayan di Desa Ketapang Barat, yaitu 3 jenis alat tangkap untuk menangkap ikan pelagis kecil, yaitu (1) Gill Net, (2) payang dan (3) jaring millennium serta 2 jenis alat tangkap untuk menangkap ikan demersal (crustacea) yaitu jaring kejer dan trammel net. Berdasarkan frekuensinya, jenis alat tangkap yang sering digunakan adalah alat tangkap payang, jaring millennium dan Gill Net. Penggunaan ketiga jenis alat tangkap ini menunjukkan bahwa nelayan di Desa Ketapang lebih dominan menangkap ikan jenis pelagis kecil.

Musim puncak ikan pelagis (ikan teri, kembung, tongkol, tenggiri dan cakalang) di Desa Ketapang Barat yaitu pada bulan Februari, April, Mei, Agustus dan Oktober. Musim puncak ikan demersal (udang dan rajungan) terjadi pada bulan Februari, Maret, Mei dan Juni. Terkait hal tersebut, maka alat tangkap Gill Net lebih dominan digunakan pada bulan Maret, April dan Mei; alat tangkap payang dominan digunakan pada bulan Februari, Agustus, Oktober dan November; alat tangkap trammel net dominan digunakan pada bulan
Februari, Maret, November dan Desember; alat tangkap kejer dominan digunakan pada bulan Mei dan Juni; serta alat tangkap jaring millenium dominan digunakan pada bulan Januari, Februari, Oktober, November dan Desember. Dalam rangka mewujudkan usaha penangkapan yang efektif dan efisien maka informasi terkait peta perkiraan penangkapan sangat diperlukan. Peta perkiraan penangkapan diharapkan tidak hanya sekedar mencantumkan titik titik koordinat lokasi daerah penangkapannya saja tetapi juga mencantumkan informasi perkiraan jenis ikan yang ada di lokasi tersebut. Dengan begitu nelayan dapat menyesuaikan penggunaan jenis alat tangkap yang sesuai dengan target tangkapannya. Berdasarkan hasil penelitian menunjukkan bahwa dalam setahun terjadi beberapa kalo perubahan musim jenis ikan pada perairan. Oleh karenanya nelayan di Indonesia khususnya nelayan kecil/tradisional harus dibekali dengan berbagai macam jenis alat tangkap sehingga dapat terus melakukan aktifitas penangkapan ketika terjadi perubahan jenis musim ikan. Alat tangkap yang digunakan tentu saja harus tidak boleh yang bersifat destruktif agar kelestaria sumberdaya ikan tetap terjaga.

\section{DAFTAR PUSTAKA}

Abdullah, R. M. 2011. Keberlanjutan Perikanan Pelagis Di Ternate Dan Strategi Pengembangannya. [Thesis]. Institut Perikanan Bogor. Bogor

Anonymous. 2010. 10 Macam Alat Penangkap Ikan di Indonesia, dalam http://haxims.blogspot. com/2010/01/10-macam-alat-penangkap-ikandi.html. diakses pada tanggal 4 maret 2013.

Badan Perencanaan Pembangunan Nasional. 2009. Data Base Pembangunan Kelautan dan Perikanan. Badan Perencanaan Pembangunan Nasional. Jakarta.

Brandt, A.V. 1984. Fish Catching Methods of the World. 3rd Ed. Fishing.

Gunawan, A. 2004. Analisis Pola Musim Penangkapan dan Tingkat Pemanfaatan Ikan Teri di Kabupaten Tuban, Jawa Timur. [Skripsi]. Institut Perikanan Bogor. Bogor.

Hurasan, M. S., H. Banjar. Alat Tangkap, Komposisi, Dan Dugaan Potensi Sumber Daya Ikan Pelagis Kecil Di Perairan Utara Maluku, Sorong dan Fak Fak. Jurnal Pen. Perikanan Laut No. 80 Th. 1993. Ambon. Hal. 46-52.

Kusnadi. 2002. Konflik Sosial Nelayan. Kemiskinan dan Perebutan Sumber Daya Perikanan. LKIS, Yogyakarta. 190 hal.

Taeran, I. 2011. Tingkat Pemanfaatan Dan Pola Musim Penangkapan Beberapa Jenis Ikan Pelagis Ekonomis Penting Di Provinsi Maluku Utara. [Thesis]. Institut Perikanan Bogor. Bogor. 